Geologica Macedonica, Vol. 35, No. 2, pp. 85-94 (2021)

On print ISSN $0352-1206$

On line ISSN $1857-8586$

UDC: $553.685 .08(497.752)$

https://doi.org/10.46763/GEOL21352085b

Original scientific paper

\title{
CHARACTERIZATION OF THE CALCITE RAW MATERIAL FROM THE MICROLOCALITIES OF SUŠIČKI MOST AND GORNA BANJICA NEAR GOSTIVAR, REPUBLIC OF NORTH MACEDONIA
}

\author{
Boško Boškovski ${ }^{1}$, Simeon Jančev ${ }^{1}$, Blagoj Pavlovski ${ }^{1}$, Arianit A. Reka ${ }^{2}$, Andrijana Čankuloska ${ }^{1}$, \\ Slobodan Bogoevski ${ }^{1}$
}

\author{
${ }^{1}$ Faculty of Technology and Metallurgy, "Ss. Cyril and Methodius" University in Skopje, \\ Rugjer Bošković 16, 1000 Skopje, Republic of North Macedonia \\ ${ }^{2}$ Faculty of Natural Sciences and Mathematics, University of Tetovo, \\ Ilinden nn, 1200 Tetovo, Republic of North Macedonia \\ bboskovski@tmf.ukim.edu.mk
}

\begin{abstract}
A b s t r a c t: The aim of this research is characterization of the calcite raw material from two microlocalities: Sušički Most and Gorna Banjica near Gostivar. The properties of the calcite raw materials were defined applying complex examinations. XRD analysis determined the presence of calcite and dolomite as basic mineral phases, which was confirmed by optical transmission microscopy. The dominant content of $\mathrm{CaCO}_{3}$ was defined by chemical analysis. ICP-AES analysis confirmed a high degree of purity of the raw materials. DTA/TGA correlate with other analyses. Some basic physical properties of the raw materials were also determined. Additionally, the parameters of the mechanical preparation have been optimized. According to the presented results, the calcite materials which have very similar composition and approximately the same properties have a wide spectrum of application possibilities.
\end{abstract}

Key words: calcite; Sušički Most; Gorna Banjica; characterization; mechanical preparation

\section{INTRODUCTION}

Calcite raw materials are widespread in the Republic of North Macedonia (Stojanović, 2005; Temovski, 2012; Arabadžiev et al., 2001). Dominantly calcite raw materials are present in the northwestern region of the state (Petkovski, 1982;
Bogoevski et al., 2004; Hristova et al., 2003). In this research the raw materials from two microlocalities, Gorna Banjica and Sušički Most, were examined (Figures 1-3).

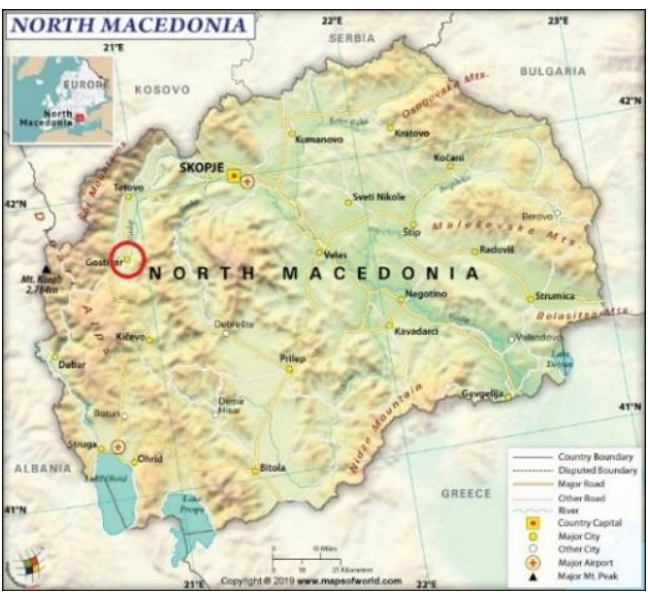

(a) Geographical map

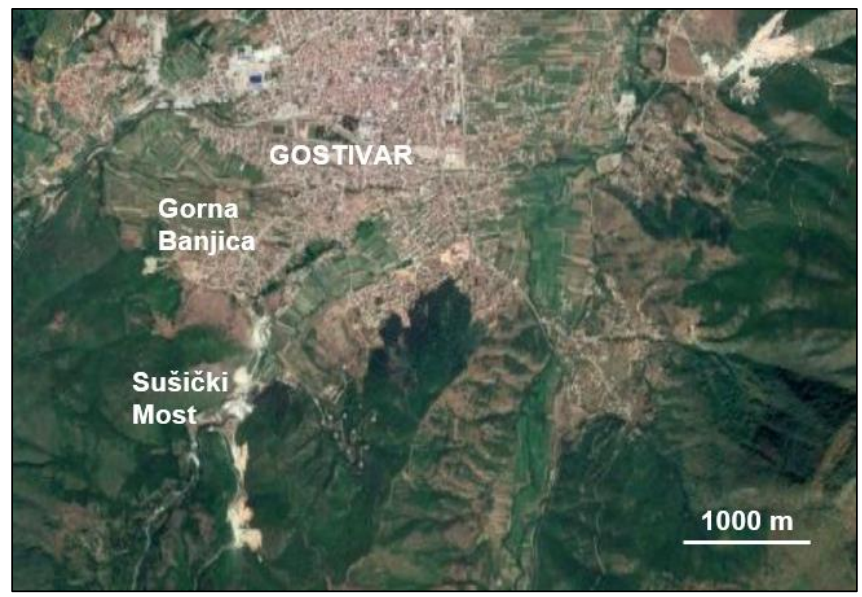

(b) Satellite map

Fig. 1. Locations of Gorna Banjica and Sušički Most 


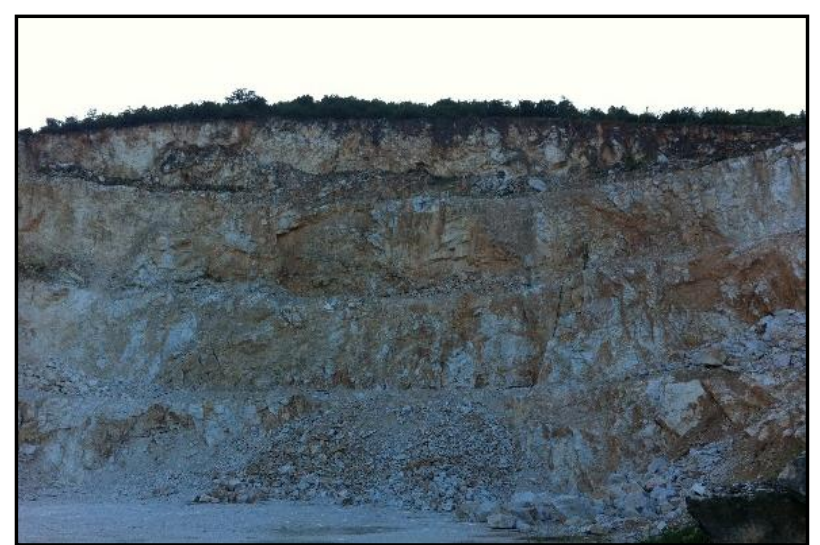

Fig. 2. Deposit in the microlocality Sušički Most

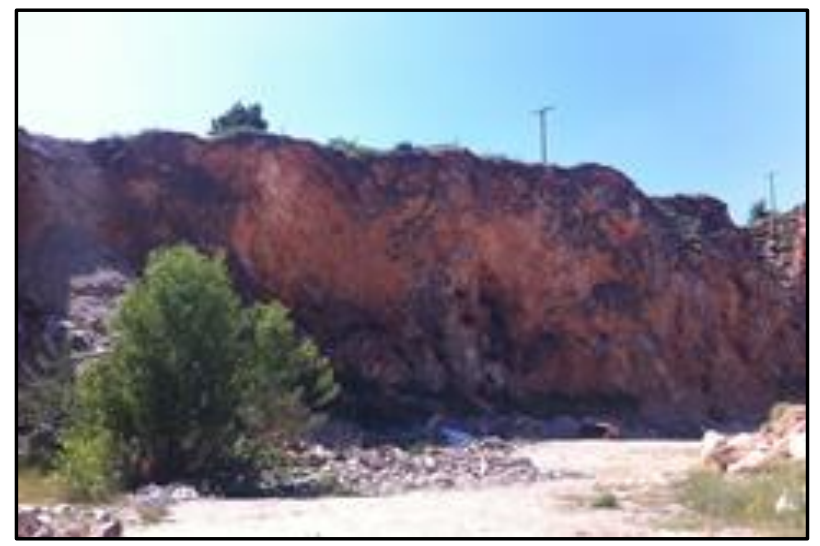

Fig. 3. Deposit in the microlocality Gorna Banjica

The Sušički Most and Gorna Banjica microlocalities are at distance of near $1 \mathrm{~km}$. In the deposits are present marbles, phyllite schists and river benches, which occur within the area and extend in the nearby surroundings.

The marbles at this locality are found interlayed within chlorite and amphibole schists, laying concordantly. They have coarse grained texture, with a uniform distribution of calcite crystal grains in the rock. The basic mass is of white-grayish color, with a brownish varieties that are found in small quantities. The color varies in the horizontal and vertical directions. In spite of color variations, the calcite raw material has a relatively homogeneous chemical composition.

In the past, quarries processed the raw materials to final products in a form of slabs of various sizes and dimensions, such as: floor slabs, stair slabs and interiors. During quarrying of the blocks and their processing, waste material is generated in large amounts. An increasing demand for white filler has imposed the need for utilization of the waste material. Therefore, the waste material was mainly used over a long period of time as a roadbase product.

Proper utilization of the waste material has a positive impact on the final financial effects of the total activities. Therefore, the main goal of this research is to define the basic physical and chemical properties of the calcite raw materials, for a higher profitable application such as in the ceramic industry (Ali et al., 2015; Amidi et al., 2015), animal feed industry (Abegaze, 2012; Pelicia et al., 2009), pharmaceutical industry (Budhika, 2011; Chaheen et al., 2018), and other industries.

\section{MATERIALS AND METHODS}

The calcite samples colellected for analysis (Figure 4) are of white-grayish color. Locally, brownish film is present (dominantly in the tectonic fracture) of insoluble egsogenic products of the surrounding area.

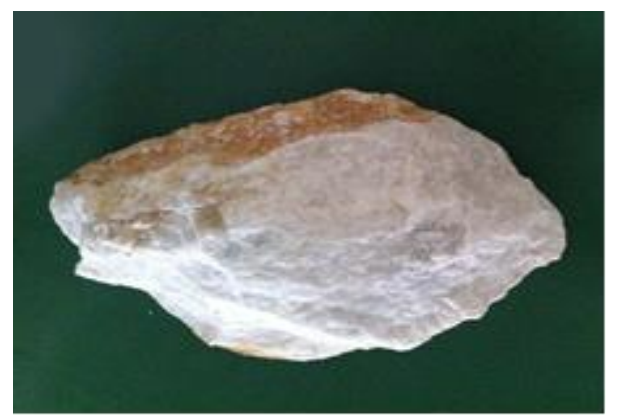

(a)

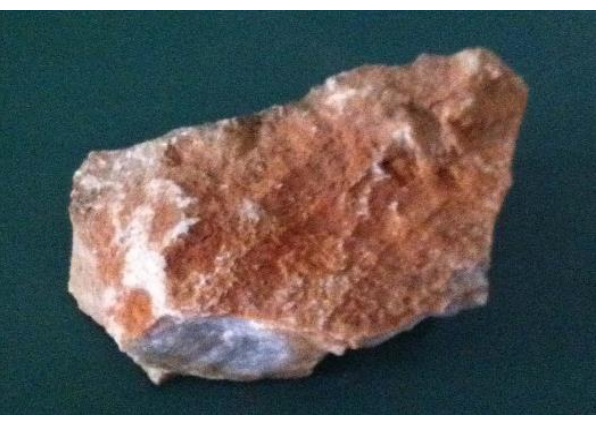

(b)

Fig. 4. Macroscopic figure of the raw material:

(a) Sušički Most and (b) Gorna Banjica 
For characterization of the raw materials, chemical analysis, X-ray analysis, DTA/TGA analysis, and mineralogical-petrographic examinations were applied. X-ray analysis was performed on DRON X-ray diffractometer $\left(2 \theta=2-60^{\circ} ; U_{\mathrm{A}}=38 \mathrm{kV}\right.$; $I_{\mathrm{A}}=18 \mathrm{~mA} ; 1 \% \mathrm{~min}$; $\left.\mathrm{CuK} \alpha / \mathrm{Ni}\right)$. Chemical composition of the raw materials was defined by silicate chemical analysis (Zafirovski et al., 1974; Bogoevski et al., 2014; Reka et al., 2014; Pavlovski et al., 2011). The quantities of trace elements were determined by ICP-AES analysis (Varian 715-ES). Thermal analysis were performed on DTA-TG Perkin Elmer-7 Diamond instrument, in nitrogen atmosphere with heating rate $20 \% \mathrm{~min}$ from ambient to $1000^{\circ} \mathrm{C}$. Mineralogical-petrographic examinations were performed applying transmission optical method, on the microscope SM-POL Leitz Westlar.
Operations of crushing and milling were applied in the process of mechanical preparation of the materials (Knežević, 2001; Nikolovski, 1995; Bogoevski et al., 2016). Initially the raw materials were treated on a jaw crusher Blake. Then the materials were three time treated $(8,3$ and $1 \mathrm{~mm})$ on a roller crusher Denver B7141A. In the next stage of the preparation process, dry milling was applied into a porcelain mill with balls. The duration time of milling was 15, 30, 45 and $60 \mathrm{~min}$. The material: ball ratio is $1: 2.5$ and the velocity of rotation is $\omega=65^{\circ} / \mathrm{min}$. A wet sieve analysis was conducted for the various milling phases. Set of standard sieves with a perforation size of $0.032 \mathrm{~mm}$ to $0.1 \mathrm{~mm}$ were used.

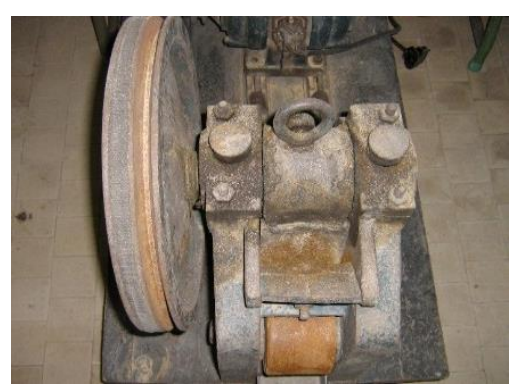

(a)

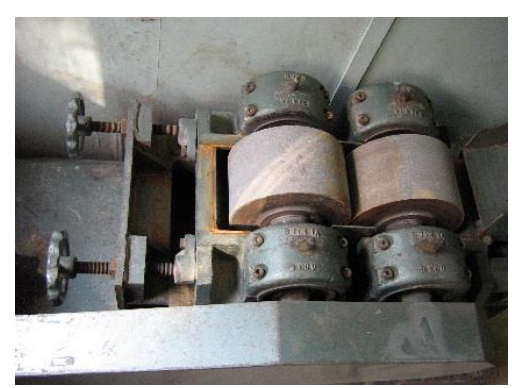

(b)

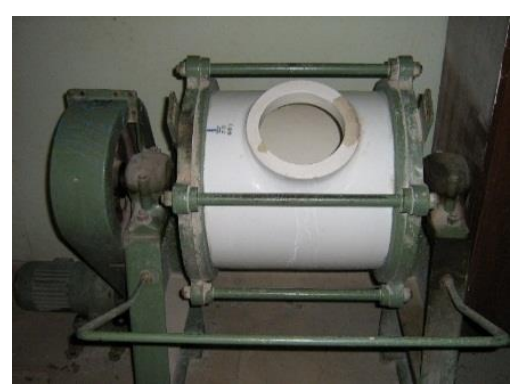

(c)

Fig. 5. Mechanical preparation of the material

(a) jaw crusher, (b) roller crusher and (c) porcelain mill with balls

\section{RESULTS AND DISCUSSION}

XRDs of the raw materials are presented on Figures 6 and 7. From the XRD, calcite and dolomite were identified as the dominant minerals. The raw material also contains minor quantities of quartz and feldspar.

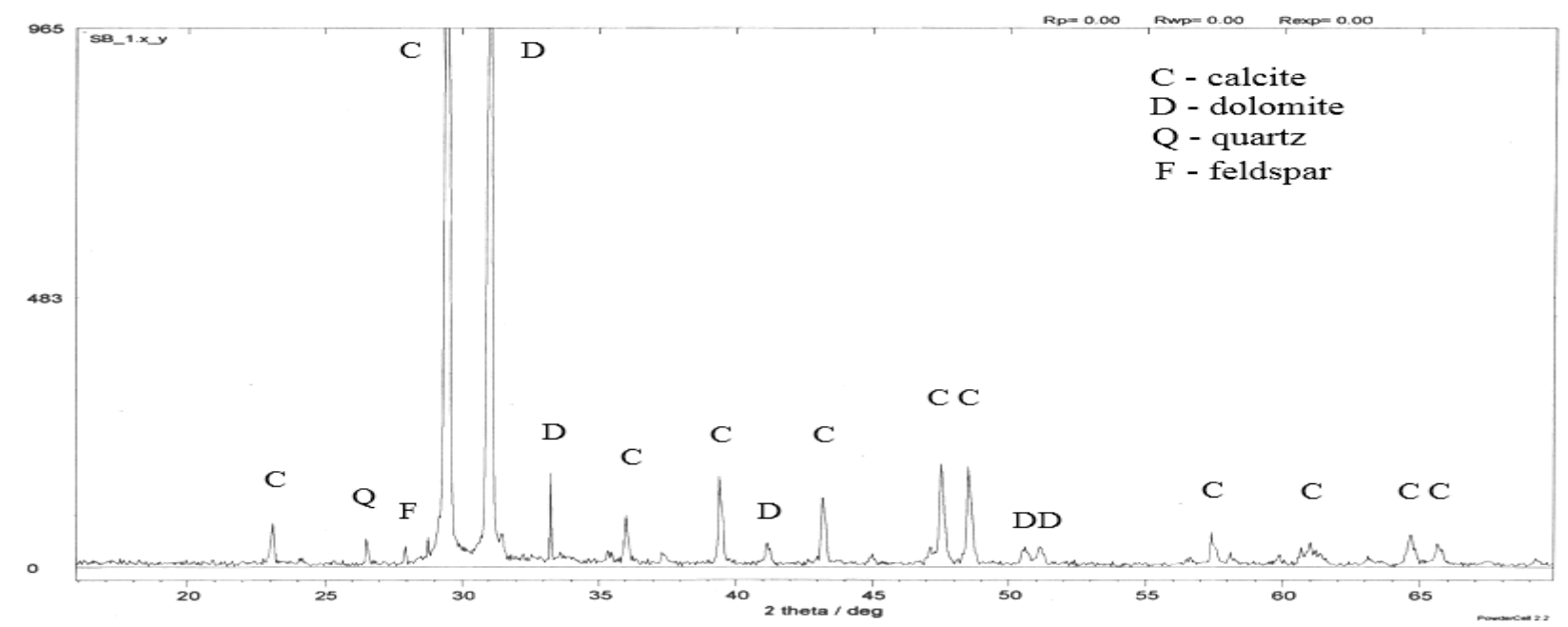

Fig. 6. XRD of the raw material from Sušički Most 


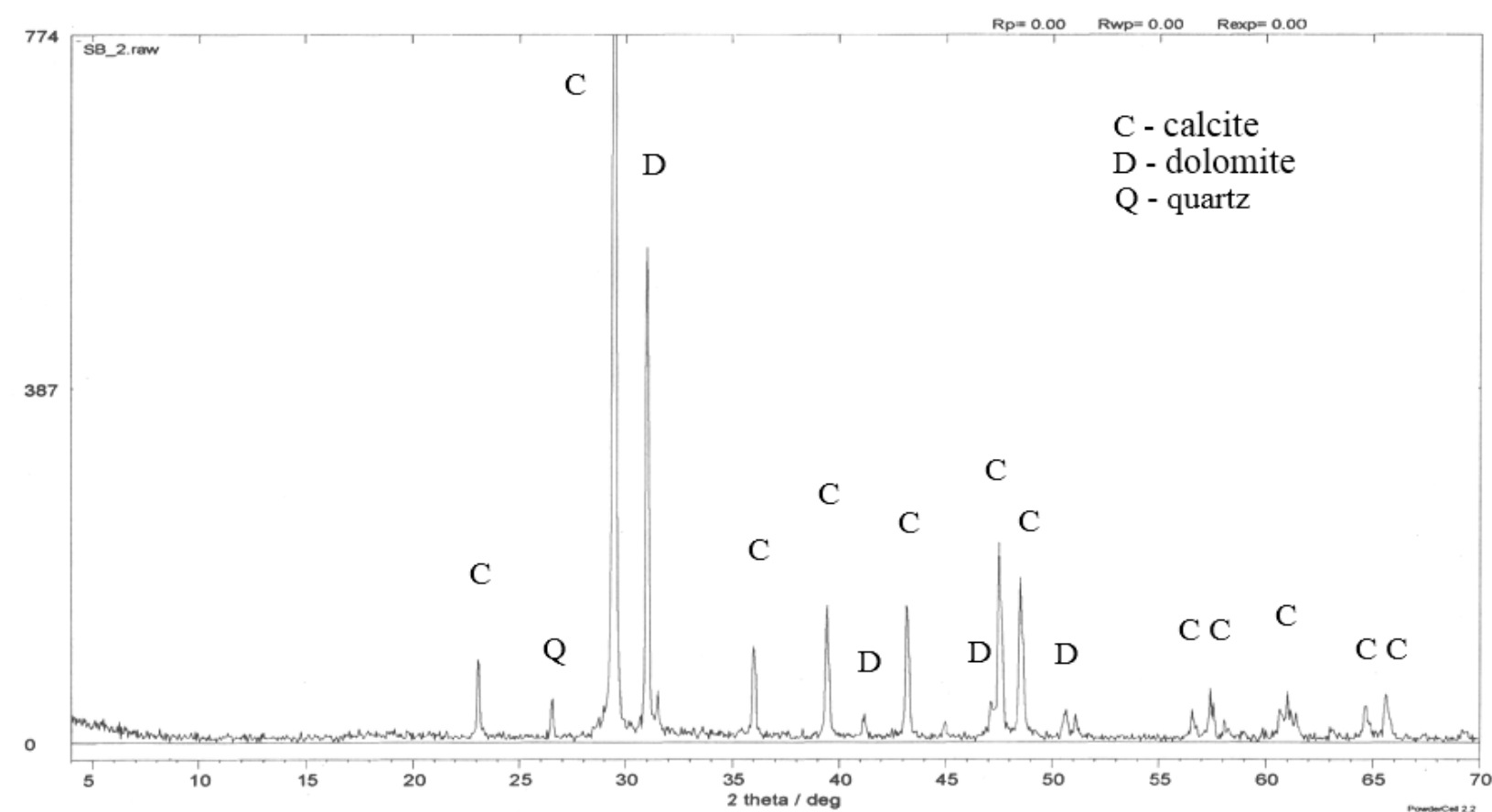

Fig. 7. XRD of the raw material from Gorna Banjica

Chemical composition of the raw materials is presented in Table 1 . The dominant mass content of over $53 \%$ has $\mathrm{CaO} . \mathrm{MgO}$ has a minimum mass content of 1.81 and $1.53 \%$. According to $\mathrm{XRD}$, the raw materials contain feldspar and quartz. Therefore, minor quantities of $\mathrm{Na}_{2} \mathrm{O}$ and $\mathrm{K}_{2} \mathrm{O}$, as well as $\mathrm{SiO}_{2}$, were determined in the chemical composition. The values of weigh lost (43.49 and $43.53 \%$ ) in correlation with $\mathrm{CaO}$ content (53.02 and $53.11 \%$ ), indicate that the raw materials contain calcite dominantly.

Table 1

Chemical composition of the raw material (mass \%)

\begin{tabular}{ccc}
\hline \hline Elements & Sušički Most & Gorna Banjica \\
\hline $\mathrm{Ag}$ & $<1.0$ & $<1.0$ \\
$\mathrm{Cd}$ & $<0.5$ & $<0.5$ \\
$\mathrm{Co}$ & $<1.0$ & $<1.0$ \\
$\mathrm{Cr}$ & $<1.0$ & $<1.0$ \\
$\mathrm{Cu}$ & $<1.0$ & 2.2 \\
$\mathrm{Fe}$ & $<5.0$ & $<5.0$ \\
$\mathrm{Mn}$ & 1,6 & 1,9 \\
$\mathrm{Ni}$ & $<1.0$ & $<1.0$ \\
$\mathrm{~Pb}$ & $<2.0$ & $<2.0$ \\
$\mathrm{Zn}$ & $<1.0$ & $<1.0$ \\
\hline \hline
\end{tabular}

The presented results from X-ray and chemical analyses confirm insignificant variations between raw materials from the Gorna Banjica and Sušički Most microlocalities.

The results of ICP-AES analysis are presented in Table 2. The absence or minor quantities of trace elements indicate a high degree of purity, imposing them as the materials for the pharmaceutical industry, which is highly profitable utilization.

Table 2

ICP-AES analysis of content of trace elements (ppm) in the raw material

\begin{tabular}{lcc}
\hline \hline & Sušički Most & Gorna Banjica \\
\hline $\mathrm{SiO}_{2}$ & 0.13 & 0.25 \\
$\mathrm{Al}_{2} \mathrm{O}_{3}$ & 0.36 & 0.39 \\
$\mathrm{Fe}_{2} \mathrm{O}_{3}$ & tr. & tr. \\
$\mathrm{CaO}$ & 53.02 & 53.11 \\
$\mathrm{MgO}$ & 1.81 & 1.53 \\
$\mathrm{~K} 2 \mathrm{O}$ & 0.15 & 0.15 \\
$\mathrm{Na}_{2} \mathrm{O}$ & 0.87 & 0.91 \\
$\mathrm{SO}_{3}$ & tr. & tr. \\
$1 . w$ & 43.49 & 43.53 \\
\hline$\Sigma$ & 99.83 & 99.87 \\
\hline \hline
\end{tabular}


Because the obtained results confirm high similarity of the calcite raw materials, and taking into a consideration that the microlocalities of Gorna Banjica and Sušički Most are at distance of near 1 $\mathrm{km}$, a composite sample was examined by thermal analysis (Figure 8). The thermal analysis are in correlation with other results. Characteristically for calcite due to thermal dissociation of the carbonate, DTA curve have an endothermic peak. The TGA curve is compatible with high loss of mass.

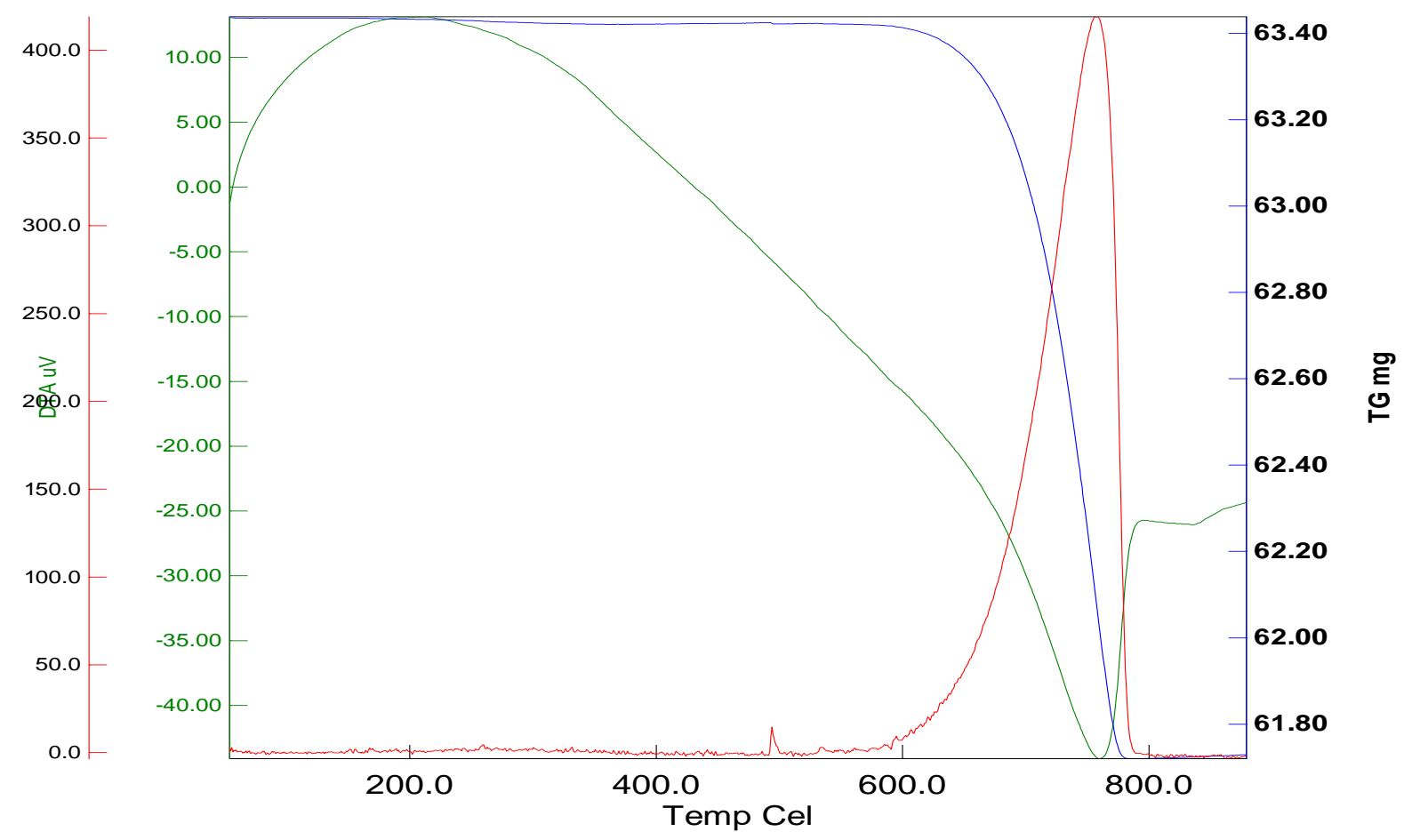

Fig. 8. DTA, TGA of the raw material (composite sample)

The raw material from Sušički Most has a partially heterogeneous structure. Calcite grains of size larger then $100 \mu \mathrm{m}$ are quantitatively dominant (Figure 9). The elongated shape of the grains indicates that the raw material was formed in tectonic zones under high pressure.
Locally rhombohedral dolomite grains are incorporated into the basic mass of calcite (Figure 10). Calcite and dolomite grains have slightly flat and sharp contacts.

Impurities of organic origin are also present (Figure 11).

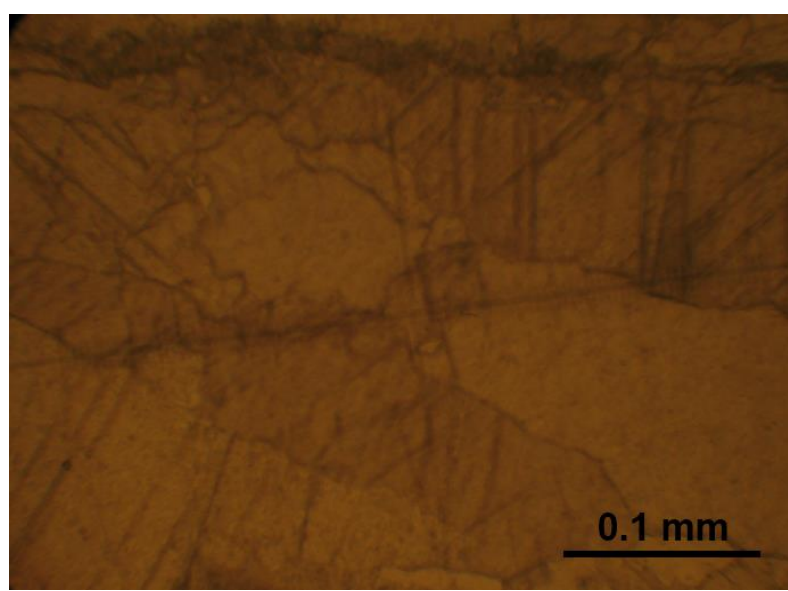

Fig. 9. Elongate calcite grains, Sušički Most 


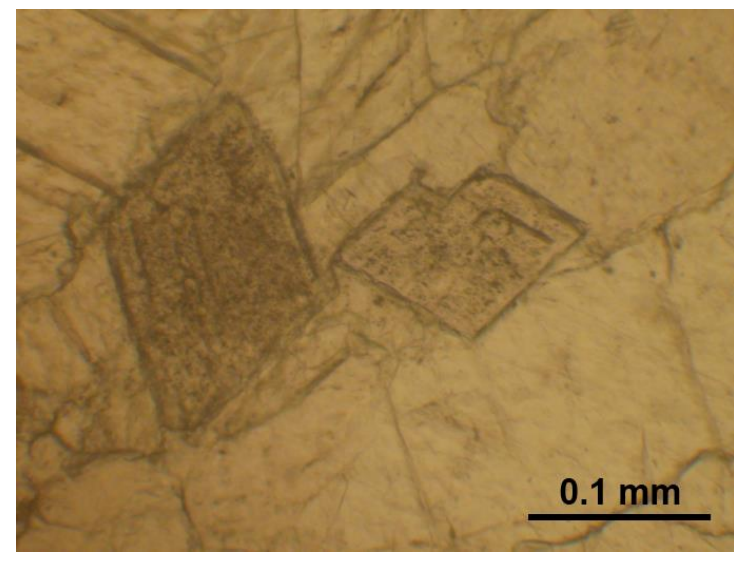

(a) $\mathrm{N}^{-}$

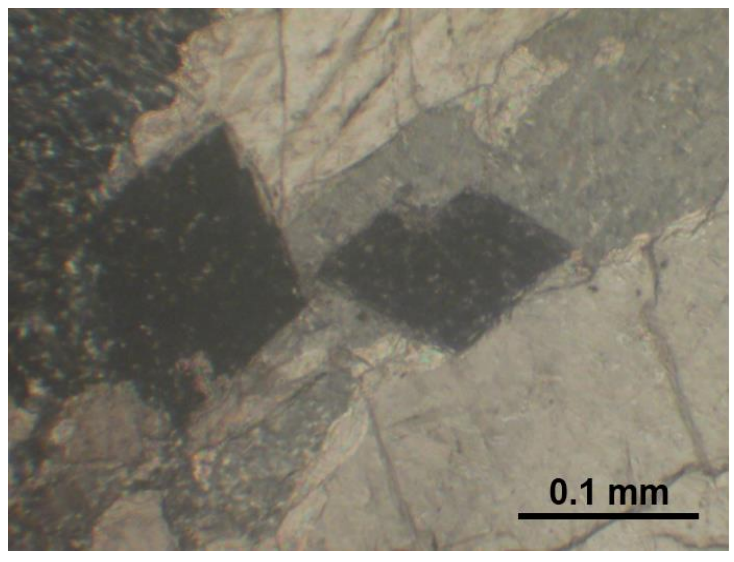

(b) $\mathrm{N}^{+}$

Fig. 10. Rhombohedral dolomite grains incorporated into the basic calcite mass, Sušički Most

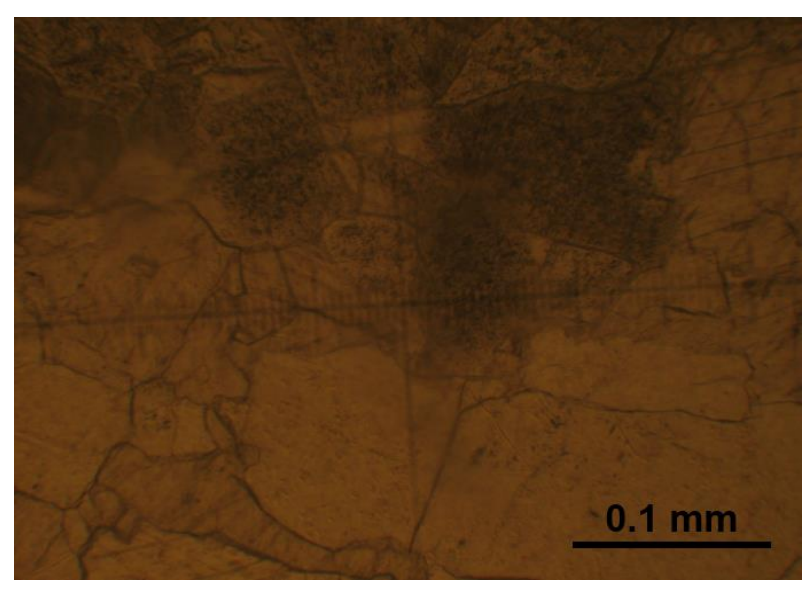

Fig. 11. Organic impurities, Sušički Most

The raw material from Gorna Banjica has a heterogeneous structure. Smaller calcite grains with dimensions $50-70 \mu \mathrm{m}$ are quantitatively dominant (Figure 12). The grains do not have a uniform shape and dimensions.

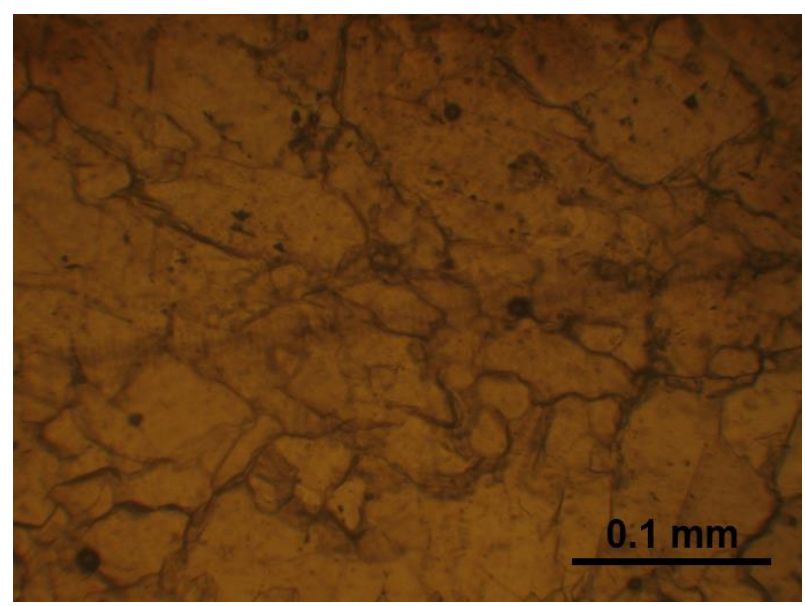

Fig. 12. Heterogeneous structure of the raw material from Gorna Banjica
Because the microlocalities have a minimum distance and are located into same tectonic zone, elongated calcite grains are also visible (Figure 13).

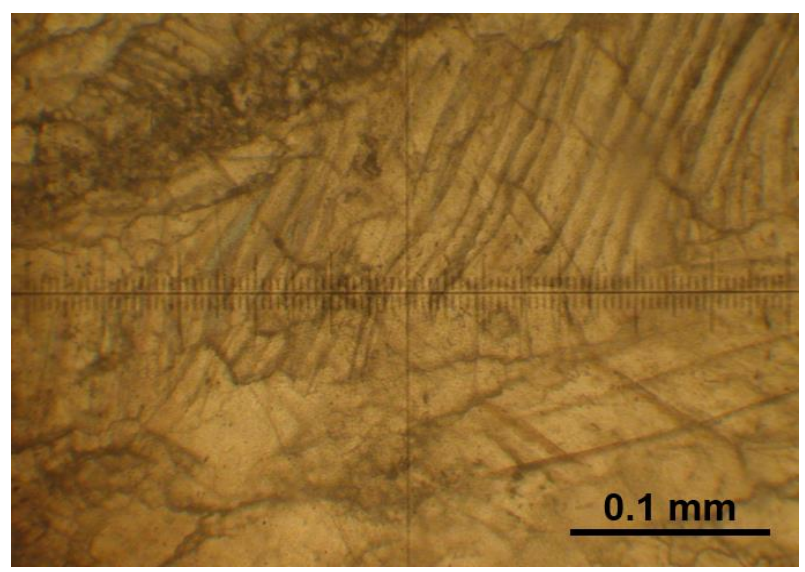

Fig. 13. Elongated calcite grains, Gorna Banjica

Brown-reddish impurities are visible in the tectonic fracture, which indicates a presence of clay as well as Fe-oxides (Figure 14).

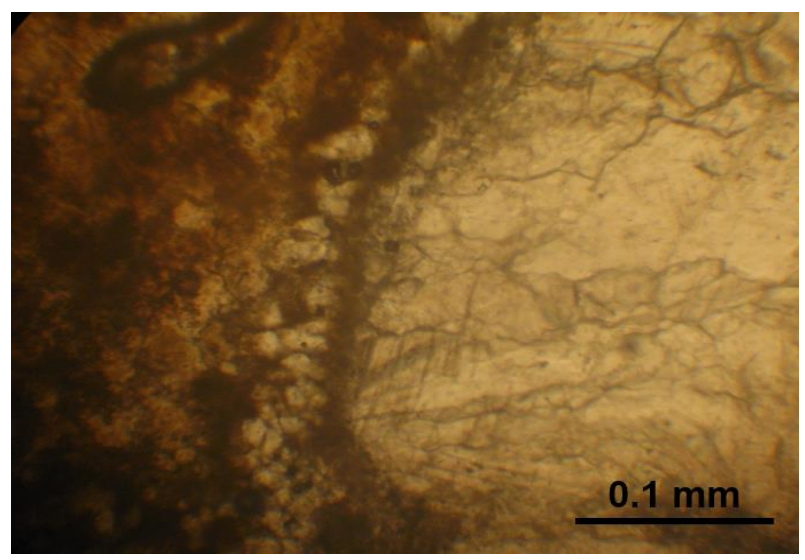

Fig. 14. Contact of white-grayish calite mass with brown-reddish impurities, Gorna Banjica 
The pressure strength as a significant mechanical property of the raw materials was also determined (Figure 15)

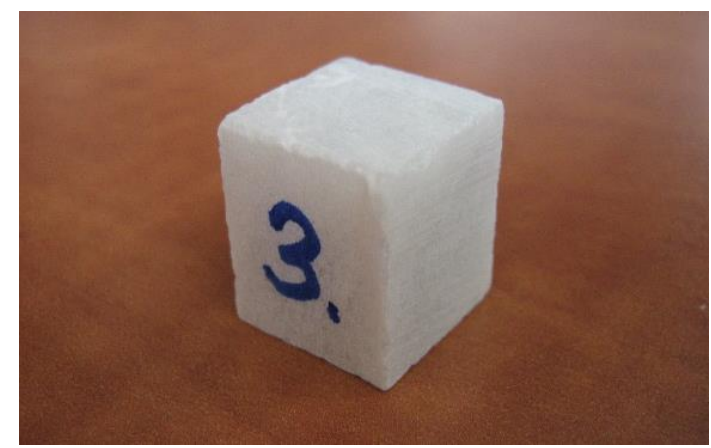

(a) Cube sample

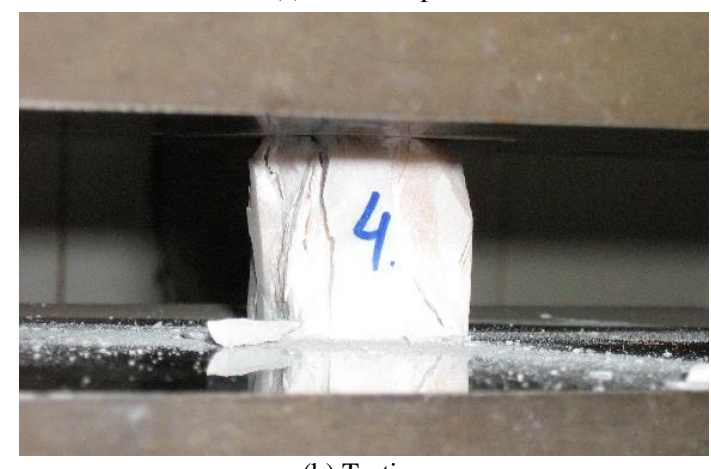

(b) Testing

Fig. 15. Pressure strenght testing

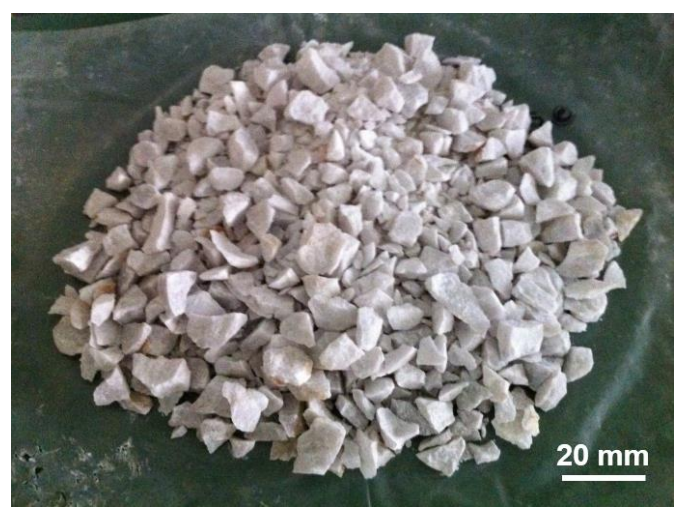

(a) Sušički Most
The basic physical properties were determined in order to have a complete preview on the raw materials (Table 3 ).

Table 3

Physical properties of the raw materials

\begin{tabular}{lcc}
\hline \hline & Sušički Most & Gorna Banjica \\
\hline Specific mass $\left(\mathrm{g} / \mathrm{cm}^{3)}\right.$ & 2.682 & 2.679 \\
Volume mass $\left(\mathrm{g} / \mathrm{cm}^{3}\right)$ & 2.718 & 2.717 \\
Total porosity $(\%)$ & 1.52 & 1.54 \\
Water absorption $(\%)$ & 0.17 & 0.17 \\
Pressure strenght $(\mathrm{MPa})$ & 95.2 & 96.0 \\
\hline \hline
\end{tabular}

In the process of mechanical preparation, the raw materials were primarily treated on a jaw crusher. As a consequence of inter contacts of grains, the calcite agregates have a flat and sharp shape after crushing (Figure 16).

The smaller grains that were generated in the advanced stage of the preparation process (roller crusher), also have a flat and sharp shape. As a consequnce, the power consumption for the mechanical preparation of the raw materials will be higher. The smaller grains that were generated in the advanced stage of the preparation process on the roller crusher, also have a flat and sharp shape (Figure 17).

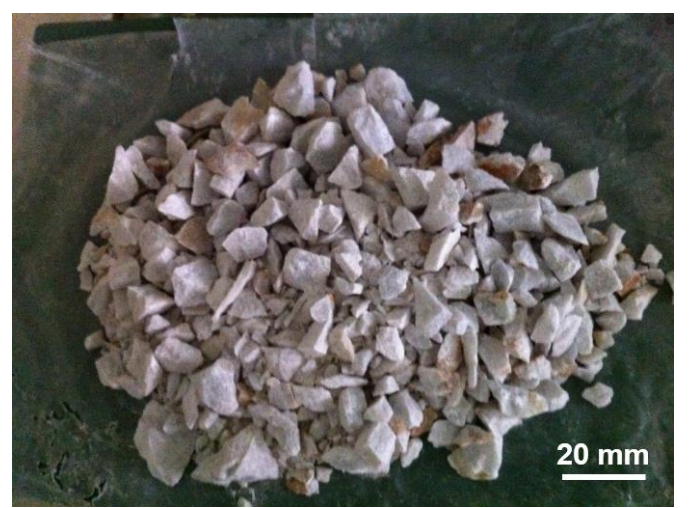

(b) Gorna Banjica

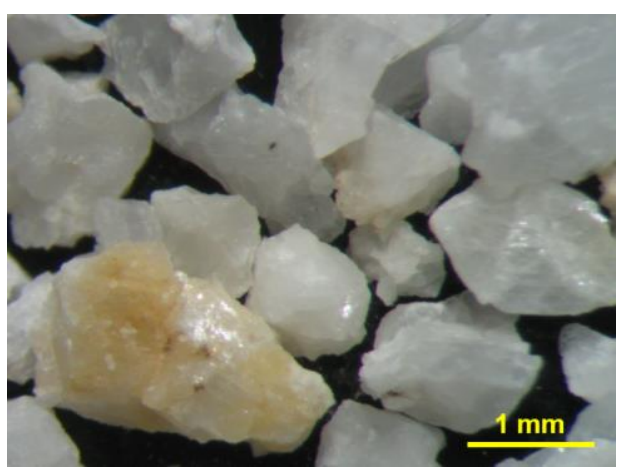

(a) Coarse fraction

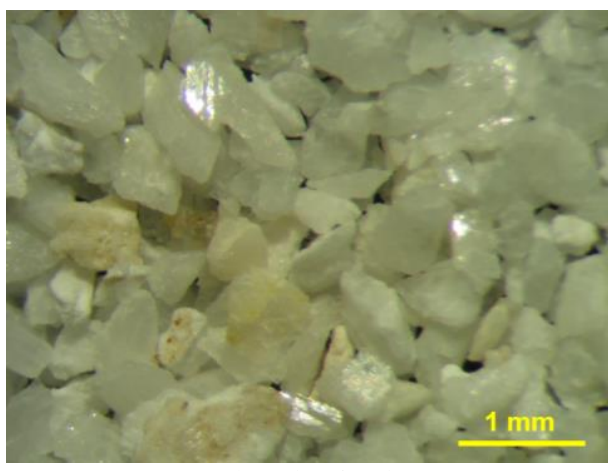

(b) Fine fraction

Fig. 17.- Calcite grains after treating on a roller crush 
As the last stage of preparation process, dry milling into a porcelain mill with balls was applied. In order to define the effects of mechanical destruction on raw materials, a wet sieve analysis was conducted for various milling phases. The results are presented in Tables 4 and 5 .

Ta ble 4

Sušički Most, granulometric wet sieve analysis of various milling phases (mass \%)

\begin{tabular}{ccccc}
\hline \hline Fraction $(\mathrm{mm})$ & $15 \mathrm{~min}$ & $30 \mathrm{~min}$ & $45 \mathrm{~min}$ & $60 \mathrm{~min}$ \\
\hline$+0,1$ & 32.43 & 6.02 & 1.42 & 0.28 \\
$-0,1+0,080$ & 8.45 & 5.76 & 1.36 & 1.04 \\
$-0,080+0,071$ & 3.60 & 5.63 & 2.45 & 1.23 \\
$-0,071+0,063$ & 6.04 & 4.40 & 4.77 & 3.55 \\
$-0,063+0,040$ & 12.16 & 17.57 & 17.35 & 10.50 \\
$-0,040+0,320$ & 3.57 & 5.44 & 4.62 & 8.08 \\
$-0,032$ & 33.75 & 55.18 & 68.03 & 75.32 \\
$\Sigma$ & 100.00 & 100.00 & 100.00 & 100.00 \\
\hline \hline
\end{tabular}

Table 5

Gorna Banjica, granulometric wet sieve analysis of various milling phases (mass \%)

\begin{tabular}{ccccc}
\hline \hline Fraction $(\mathrm{mm})$ & $15 \mathrm{~min}$ & $30 \mathrm{~min}$ & $45 \mathrm{~min}$ & $60 \mathrm{~min}$ \\
\hline$+0,1$ & 37.3 & 6.3 & 1.1 & 0.5 \\
$-0,1+0,080$ & 7.3 & 7.9 & 2.9 & 1.4 \\
$-0,080+0,071$ & 2.7 & 3.4 & 2.9 & 2.1 \\
$-0,071+0,063$ & 3.5 & 7.6 & 2.2 & 2.2 \\
$-0,063+0,040$ & 3.2 & 1.1 & 16.4 & 7.4 \\
$-0,040+0,320$ & 11.6 & 17.9 & 4.7 & 9.8 \\
$-0,032$ & 34.4 & 55.8 & 69.8 & 76.6 \\
$\Sigma$ & 100.00 & 100.00 & 100.00 & 100.00 \\
\hline \hline
\end{tabular}

The dominant size fraction is the finest $(-0.032$ $\mathrm{mm}$.). As the duration time of milling increases, the content of the finest fraction also increases. Inversely, the content of the coarsest fraction $(+0,1 \mathrm{~mm})$ decreases rapidly. The other size fractions have a minimum content. The histograms of size fractions mass content for various milling phases are presented on Figures 18 and 19.

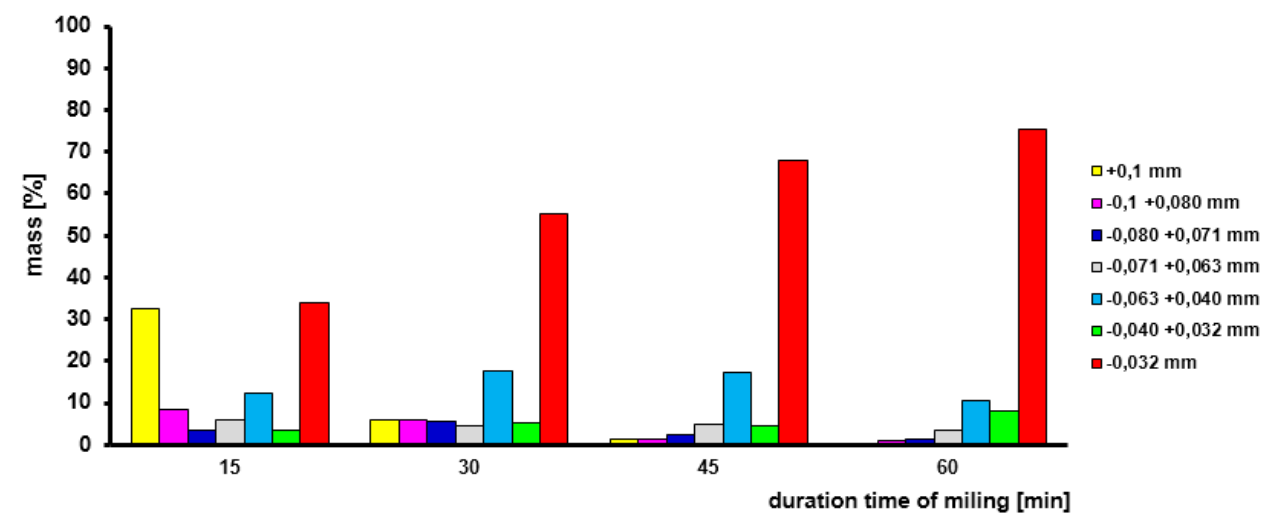

Fig. 18. Histogram of size fractions mass content of various milling phases, Sušički Most

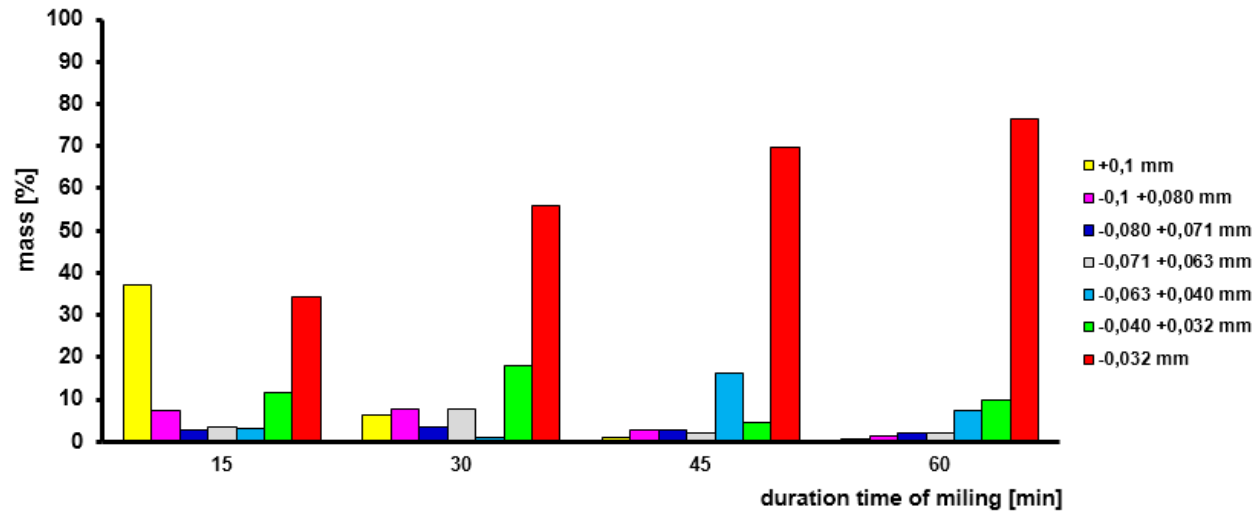

Fig. 19. Histogram of size fractions mass content of various milling phases, Gorna Banjica 
According to previously obtained results, the milling process can be implemented at specific regime in order to accomplish the previously set requirements for specific size fractions. The detailed characterization of various size fractions provides an opportunity for their specific and selective application.

\section{CONCLUSION}

According to the presented results of the complex examinations conducted in this research, it can be concluded that the raw materials from the microlocalities of Sušički Most and Gorna Banjica, from mineralogical aspect represent calcite with admixture of dolomite. The mineral species were defined by XRD analysis, chemical analysis, DTA/TGA analysis and mineralogical-petrographic examinations. The mineral phase's calcite and dolomite were formed in the tectonic zones under high pressure. As a consequence of geotectonic conditions of crystallization, the grains are finely structured with slightly flat and sharp contacts. That will increase the power consumption during mechanical preparation of the raw materials.

The calcite raw materials have a pure chemical composition. The ICP-AES analysis confirm the absence or minor quantities of the trace elements. Therefore, the raw materials can be used as an additive in the animal feed industry and pharmaceutical industry, which is higher profitable utilization. Taking into a consideration that the Gorna Banjica and Sušički Most microlocalities are at distance of near $1 \mathrm{~km}$, the obtained results indicate that there is a possibility for exploitation of the raw material from a wider region of this massif, with negligible variations in the composition and properties.

\section{REFERENCES}

Abegaze, B. (2012): Possibility of using calcite powder as a calcium supplement for livestock, Global Journal of Science Frontier Research Agriculture \& Biology, 12 (5), 42-47.

Ali, M. Y., Abdullah, M. S., Saad, S. A. (2015): Effect of calcium carbonate replacement on workability and mechanical strength of Portland cement concrete, Advanced Materials Research, 1115, 137-141.

Amidi, S., Wang, J. (2015): Surface treatment of concrete bricks using calcium carbonate precipitation, Construction and Building Materials, 80, 273-278.

Arabadžiev, D. M., Stefov, V., Stafilov, T., Boev, B. (2001.2002): Physico-chemical investigations of limestones in the Republic of Macedonia, Geologica Macedonica, Vol. 15-16, 35-41.

Bogoevski, S., Boškovski, B., Ruseska, G., Atkovska, K. (2016): Concentration of carbonate admixture from opalized tuff into one separate fraction, Geologica Macedonica, 30 (1), 89-95.

Bogoevski, S., Jančev, S., Boškovski, B. (2014): Characterization of diatomaceous earth from Slavishko Pole locality in the Republic of Macedonia, Geologica Macedonica, 28 (1), 39-43.

Bogoevski, S., Jančev, S. (2004): Phase characterization of a calcite marble from mine Spektar-Brvenica, Tetovo region, Macedonia, V International Symposium of Scientists and Specialists, Zenica, 41-48.

Buddhika, J. (2011): Pharmaceutical evaluation of calcium carbonate deposits in Sri Lanka, Pharmaceutical Journal of Sri Lanka, 2, 10-19.
Chaheen, M., Sanchez-Ballester, N. M., Bataille, B., Yassine, A., Belamie, E., Sharkawi T. (2018): Development of coprocessed chitin-calcium carbonate as cultifunctional tablet excipient for direct compression, Journal of Pharmaceutical Sciences, 107 (8), 2152-2159.

Hristova, E., Jančev, S. (2003): Characteristics of a calcite "limestone"-marble from Macedonia, used as flux material, Journal of Mining and Metallurgy, Section B: Metallurgy, 39, 3-4.

Knežević, D. (2001): Priprema mineralnih surovina, Rudarsko -geološki fakultet, Beograd.

Nikolovski, M. (1995): Podgotovka na mineralni surovini, Rudarsko-geološki fakultet, Univerzitet "Sv. Kiril i Metodij”, Skopje.

Pavlovski, B., Jančev, S., Petreski, Lj., Reka, A., Bogoevski, S., Boškovski, B. (2011): Trepel - a peculiar sedimentary rock of biogenetic origin from the Suvodol Village, Bitola, R. Macedonia, Geologica Macedonica, 25 (1), 67-72.

Pelicia, K., Garcia, E., Mori, C., Faitarone, A. B. G. (2009): Calcium levels and limestone particle size in the diet of commercial layers at the end of the first production cycle, Brazilian Journal of Poultry Science, 11 (2), 87-94.

Petkovski, P. (1982): Tolkuvač za listot Gostivar, Osnovna geološka karta na SFRJ, Sojuzen geološki zavod, Belgrad.

Reka, A., Anovski, T., Bogoevski, S., Pavlovski, B., Boškovski, B. (2014): Physical-chemical and mineralogicalpetrographic examinations of diatomite from deposit near village Rožden, R. Macedonia, Geologica Macedonica, 28 (2), 121-126. 
Stojanović, M. (2005): Naoǵališta na nemetalni surovini vo Makedonija, Skopje.

Temovski, M. (2012): Površinska rasprostranetost na karstnite karpi vo Republika Makedonija, Geogravski razgledi, 46, $21-35$.
Zafirovski, S., Pavlovski, B., Sapunov, P. (1974): Priračnik za nemetalni surovini i proizvodi so metodi za nivno ispituanje, Univerzitet “Sv. Kiril i Metodij”, Skopje.

Р е 3 и м е

\title{
КАРАКТЕРИЗАЦИЈА НА КАЛЦИТНИ СУРОВИНИ ОД МИКРОЛОКАЛИТЕТИТЕ СУШИЧКИ МОСТ И ГОРНА БАЫИЦА БЛИЗУ ГОСТИВАР, СЕВЕРНА МАКЕДОНИЈА
}

\author{
Бошко Бошковски ${ }^{1}$, Симеон Јанчев ${ }^{1}$, Благој Павловски ${ }^{1}$, Арианит А. Река ${ }^{2}$, \\ Александра Чанкулоска ${ }^{1}$, Слободан Богоевски ${ }^{1}$

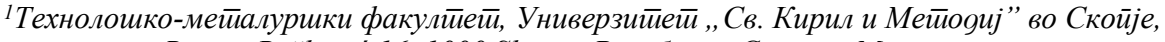 \\ Rugjer Bošković 16, 1000 Skopje, Рейублика Северна Макеgонија

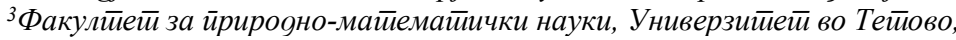 \\ Илиноенска бб, 1200 Тейово, Рейублика Северна Макеgонија \\ bboskovski@tmf.ukim.edu.mk
}

Клучни зборови: калцит; Сушички Мост; Горна Бањица; карактеризација; механичка подготовка

Целта на ова истражување е карактеризација на калцитните суровини од два микролокалитета, Сушички Мост и Горна Бањица, близу Гостивар. Особините на калцитните суровини се дефинирани со примена на комплексни испитувања. Анализата XRD детерминира присуство на калцит и доломит како основни минерални фази, што беше потврдено и со оптичка трансмисиона микроскопија. Доминантниот удел на $\mathrm{CaCO}_{3}$ беше дефиниран со хемиска анализа.
Анализата ICP-AES го потврди високиот степен на чистотата на суровините. DTA/TGA е во корелација со другите анализи. Некои од основните физички особини исто така се определени. Дополнително се оптимизирани и параметрите на механичката подготовка на суровините. Според добиените резултати, калцитните суровини, кои имаат многу сличен состав и приближно исти особини, имаат широк спектар на практична примена. 